\title{
Mining Waste in the Circular Economy - Idea Versus Reality
}

\author{
Izabela Kotarska $^{{ }^{*}}$, Barbara Mizera ${ }^{1}$, and Pawet Stefanek ${ }^{2}$ \\ ${ }^{1}$ KGHM Cuprum Research \& Development Centre, 53-659 Wrocław, ul. W. Sikorskiego 2-8, Poland \\ ${ }^{2}$ KGHM Polska Miedź SA, Hydrotechnical Division, 59-305 Rudna, Polkowicka 52, Poland
}

\begin{abstract}
This article constitutes an analysis of the feasibility of the application of the so popular presently idea of the circular economy in the area of mining waste management. It describes the specificity of the mining waste generated during the mining and the enrichment of copper ore, i.e. waste rock (gangue), tailings. That specificity results first of all from the character of the processes where the waste are generated and the amount of them. The waste properties are described, the implemented methods of handling it are presented, as well as the prospective technologies of recovery developed in the range of research works. The presented examples show that the implemented methods of waste rock recovery can be an illustration and model of the functioning of the circular economy (or in other words for this case wasteless economy). However, as it comes to the flotation tailings the fact has been emphasised that the research studies are being carried out for decades aimed to search a possibility to recover as much waste as possible. Those deliberations lead to the conclusion that at present in reality the only method of that waste management is to deposit it in an environmentally safe way.
\end{abstract}

\section{Introduction}

The idea of the circular economy consists in the closing of the product life cycle that means a sequence: production - use - use the waste in subsequent production cycle (the term called "from cradle to cradle"). The essence of that approach is the use of the waste generated within the product life cycle and by this limitation of the use of raw materials, reduction of the amount of stored waste, and increase the stream of the waste used in recovering and recycling $[1,2]$.

It should be emphasized here that the philosophy of the circular economy refers to all the stages of the product life cycle: from designing through production and consumption up to the issues directly connected with the management of generated waste. If the generation of waste, proceeding with full care, could not be prevented, then the assumption is the full use of its raw material potential, and then the energetic potential as well [3].

In the area of the commonly used consumer goods (and in consequence - municipal waste) it is not difficult to imagine the implementation of that idea. We have already become accustomed to sort our everyday waste into various fractions. Everywhere function plants for recovering plastic materials and composting plants, recovering of scrap metals is

\footnotetext{
${ }^{*}$ Corresponding author:ikotarska@,cuprum.wroc.pl
} 
obvious.

However, in the case of industry, particularly for such its branch as mining, the idea of the closed circular economy, despite the unquestionable image value it carries, can be very difficult for achivement.

The article is an analysis of the feasibility of the implementation of the idea of the circular economy in the area of copper ore mining, and more precisely, in the area of handling the biggest, in terms of amounts, masses of the material generated as a result of of copper ore mining and processing conducted by KGHM Polska Miedź S.A.

\section{Characteristics of the Mining Waste Generated in KGHM Polska Miedź S.A.}

The copper ore deposits mined by KGHM Polska Miedź S.A. are located in the South-West Poland (Fig. 1) at the depth of several hundred up to 1,500 m. Copper minerals occur in three main lithology types. The individual copper ore types are: sandstone, shale and carbonate, with the average content of $\mathrm{Cu}$ up to $1.84 \%$ and $\mathrm{Ag} 52.5 \mathrm{~g} / \mathrm{Mg}$. The mining of copper ore in Poland is concentrated in three underground mines: Lubin, Rudna, and Polkowice-Sieroszowice. The processing of copper ore takes place in ore enrichment plants, and the production of copper, silver, and other products in the smelting plants in Głogów and Legnica and the Cedynia rolling mill. KGHM Polska Miedź S.A. conducts the mining of copper ores in underground mines. The yearly output of copper ore is up to 30 million $\mathrm{Mg}$.

The waste materials generated directly in the process of mining ores from deposits and their processing (enrichment) are:

- waste rock,

- the waste from copper ore enrichment process (tailings).

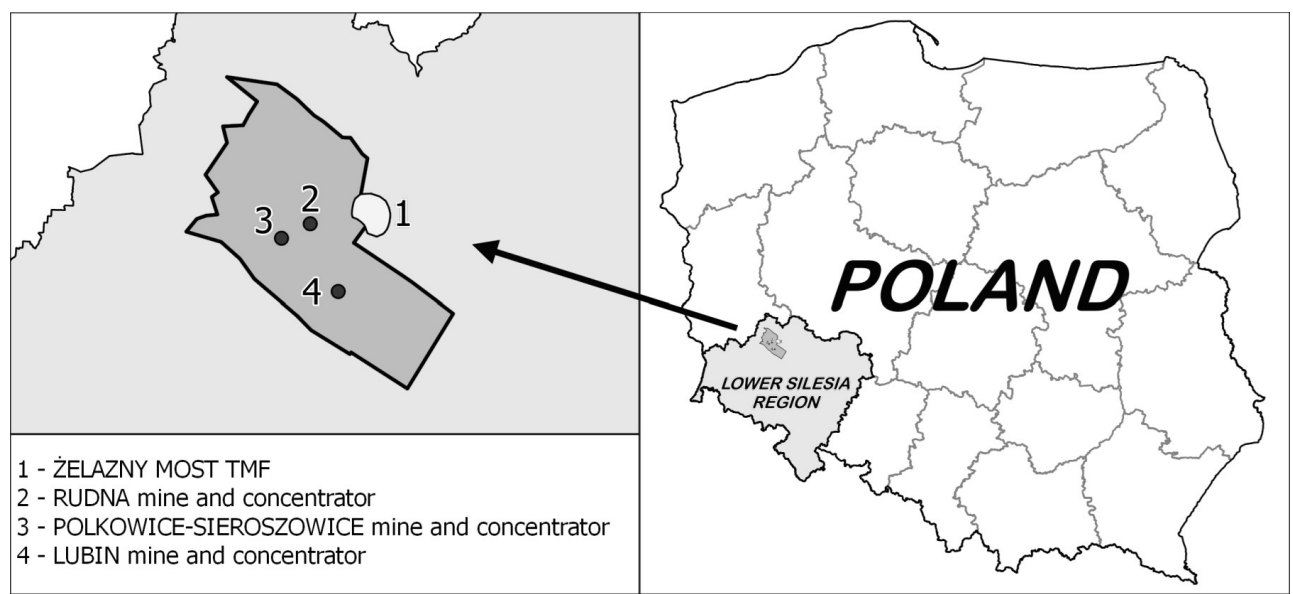

Fig. 1 Location of copper ore mining and processing objects in Lower Silesia Region.

\subsection{Waste rock}

The waste rock generated due to the exploitation of the copper ore deposit comes into existence during both preparatory mining operations as well as in the process of copper ore deposit mining. Rock masses (waste rock) accompanying copper ore, except for fragmentation, are a natural lithosphere element built mainly from sandstone, dolomites, anhydrites, rock salt with anhydrite interlayers, and also limestones, shales, and marls. 
Waste rock is formed by the following minerals: calcite, anhydrite, gypsum, loam minerals, quartzes, siderite, muscovite, and organic substances.

The amount of the gangue coming into existence as a result of copper ore exploitation is about 3.5 up to 4 million $\mathrm{Mg} /$ year.

The limitation of the amount of the generated waste rock is accomplished, as far as possible, by the use of pure, selective working of deposit and conducting headings in the way that limit to the maximum the gangue ripping in the deposit roof or dinting.

\subsection{Flotation tailings}

The copper ore delivered from KGHM Polska Miedź S.A. mines is enriched in the flotation process in the Ore Enrichment Plants which are located in the Lubin, Polkowice, and Rudna regions. The level of mineralization of Polish copper ores not exceeding $2 \%$ causes that during their enrichment about $94 \%$ of the output is separated in the form of waste. This means that at the present mining level amounting to 30 million $\mathrm{Mg}$ per year up to $28 \mathrm{mln}$ $\mathrm{Mg}$ of post-flotation waste is generated.

The amounts of tailings carried out in the KGHM Polska Miedź S.A. plants of ore enrichment in $2014-2017$ is shown in Table 1.

Table 1. Amounts of tailings from copper ore enrichment process in $2014-2017$.

\begin{tabular}{|c|c|c|c|c|}
\hline Year & 2014 & 2015 & 2016 & 2017 \\
\hline Amount [Mg] & 29175491 & 29667253 & 29903424 & 29689070 \\
\hline
\end{tabular}

Flotation tailings are actually ground waste rock of inert chemical character. Basic components of enriched ores are quartz and dolomite. The differences in composition of flotation tailings from individual concentrators result from different shares of these minerals in enriched ore. In flotation tailings from ZWR Polkowice the carbonate rock is predominant (dolomite mainly), in tailings from ZWR Rudna and Lubin - sandstone. Carbonate tailings grains are finer, their majority is particulate and claylike fraction, the sand fraction is lower than $10 \%$. The mineral composition of flotation tailings is given in the Table 2 and their grain size in the Table 3.

Table 2. Average mineral composition of flotation tailings [4].

\begin{tabular}{|l|c|c|}
\hline \multirow{2}{*}{ Mineral } & \multicolumn{2}{c|}{ Concentrator / Content [\%] } \\
\cline { 2 - 3 } & Lubin, Rudna & Polkowice \\
\hline Dolomite & 29.95 & 58.3 \\
\hline Quartz & 44.46 & 6.85 \\
\hline Calcite & 7.70 & 7.82 \\
\hline Kaolinite & 4.76 & 3.29 \\
\hline Gypsum & 1.65 & 4.70 \\
\hline Biotite & 3.30 & 1.12 \\
\hline Feldspar & 1.35 & 0.82 \\
\hline Claylike-carbonate substances & 8.35 & 4.78 \\
\hline Ore materials & 1.10 & 1.32 \\
\hline
\end{tabular}

Table 3. Average grain size composition of flotation tailings from individual concentrators [5].

\begin{tabular}{|l|c|c|c|c|c|}
\hline \multirow{2}{*}{ Concentrator } & \multicolumn{5}{|c|}{ Granulation (share \%) } \\
\cline { 2 - 6 } & $\begin{array}{c}\mathbf{>} \mathbf{0 , 2} \\
\mathbf{m m}\end{array}$ & $\begin{array}{c}\mathbf{0 , 2} \mathbf{- 0 , 1} \\
\mathbf{m m}\end{array}$ & $\begin{array}{c}\mathbf{0 , 1} \mathbf{- \mathbf { 0 , 0 7 5 }} \\
\mathbf{m m}\end{array}$ & $\begin{array}{c}\mathbf{0 , 0 7 5} \mathbf{- 0 , 0 4 5} \\
\mathbf{m m}\end{array}$ & $\begin{array}{c}<\mathbf{0 , 0 4 5} \\
\mathbf{m m}\end{array}$ \\
\hline $\begin{array}{l}\text { ZWR } \\
\text { Polkowice }\end{array}$ & - & - & 1.87 & 8.29 & 89.84 \\
\hline ZWR Lubin & 3.4 & 23.1 & 23.1 & 11.7 & 38.7 \\
\hline
\end{tabular}




\begin{tabular}{|l|l|l|l|l|l|}
\hline ZWR Rudna & 5.4 & 31.1 & 8.7 & 7.2 & 47.6 \\
\hline
\end{tabular}

Calcium and magnesium in flotation tailings are present as carbonates, heavy metals as sulphides: $\mathrm{Cu}$ as chalcocite $(\mathrm{CuS})$, bornite $\left(\mathrm{Cu}_{5} \mathrm{FeS}_{4}\right)$, chalcopyrite $\left(\mathrm{CuFeS}_{2}\right)$, covellite $(\mathrm{CuS})$; $\mathrm{Pb}$ mainly as galena $(\mathrm{PbS})$, zinc and nickel in a form sulphides as well and often as silicates. Alcaline character of waste minerals $(\mathrm{pH}$ of water extract $=7,5-8,5)$ in practice prevents the sulphides oxidation reaction to dissolved forms.

\section{Mining Waste Management}

Waste rock (gangue) is used in the recovery processes, underground, within the mining techniques, i.e.:

- for the backfilling of mined headings/workings and post-mining voids as a material for the so called dry filling,

- for the backfilling of the voids that were formed as a result of mining as the material for supplemental sealing),

- for the backfilling of the headings that require strengthening and stabilisation, including:

- under support piles as a bed.

- under support piles as a filling material,

- for the hardening of underground mine roads.

In a word, the waste (gangue) rock remains underground in the mine. The usage of waste rock within the underground mining techniques is most proper way of its management, that eliminates its negative impact on the natural environment, and at the same time it affects the reduction of the direct mining impact on the land surface, being connected with the formation of post-mining voids.

The processing waste from the copper ore enrichment process is sent to the flotation tailings management facility "Żelazny Most" located near the system installation. The Żelazny Most tailings pond is currently the only site for the deposition of flotation tailings from the three mines, and consequently the facility represents a key component of the production process, without which the production of copper concentrate would not be possible.

The amount of waste (stored in the object) is about 18 million $\mathrm{Mg}$ per year. Some of that amount (about $40.000 \mathrm{Mg}$ per year) of the post-flotation waste is used in the process of neutralization of sulphuric acid $[6,7]$.

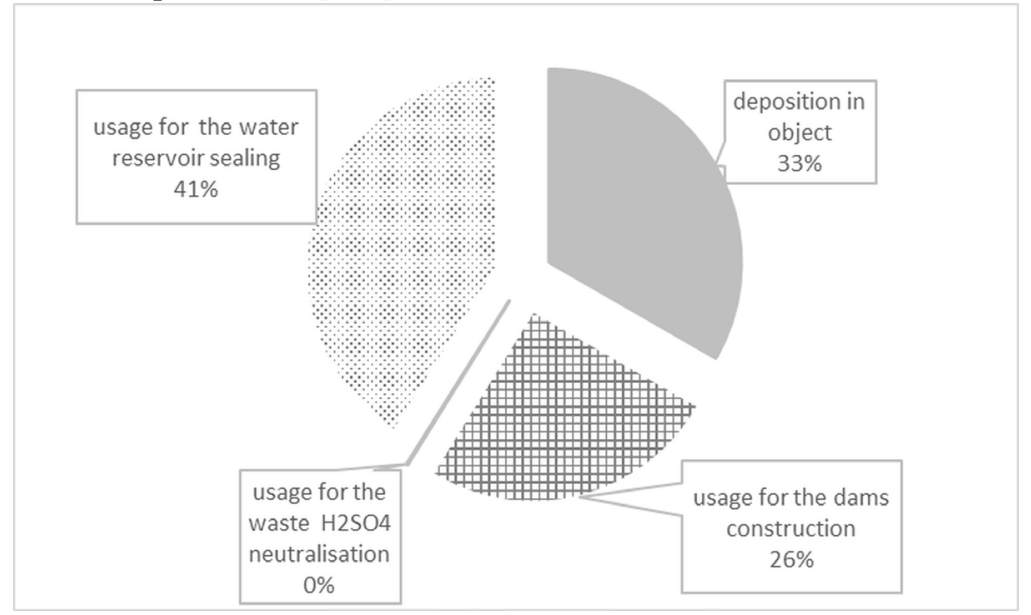

Fig. 2. Flotation tailings manangement - current state. 
Currently the main direction of flotation tailings recovery is to use it where it is disposed: in the facility for the deposition of the waste from flotation: the coarse-grained processable waste is used for the construction of facility barriers, and the fine-grained one as a material sealing the bottom of the water reservoir in the facility. This way about 18 million $\mathrm{Mg}$ of the flotation tailings per year is used. In practice, there are no other methods in use for recovery of flotation tailings. Therefore, in fact, waste material is not used in new projects, it is not an alternative for natural mineral materials.

\section{Possibilities and Directions of Flotation Tailings Management}

The activities aimed to work out an effective technology of the recovery of the tailings in other processes have been conducted virtually from the beginning of the operation of the copper industry in Poland. Many technologies have been developed and the tests how to use this kind of waste carried out:

- for the production of building materials - a polymeric building material based on waste sulphur and the flotation of copper ore was worked out [8]

- for the production of mineral binder - the obtained binder was featured by the properties of hydraulic lime, mainly thanks to some content of bicalcium silicate and active silica $\left(\mathrm{SiO}_{2}\right)$ [9],

- for the production of both aerated and foamed concrete - for the production of aerated concrete sandstone waste is fit, whereas for foamed concrete - carboniferous waste; the obtained product were meeting the requirements of the applicable standards [10],

- for the production of porous aggregates - a possibility of the production using aggregate waste by the agglomeration method after a correction of the composition by adding silicate and clay slurry [11],

- for the production of mining concrete blocks - the post-flotation waste can be used after mixing with furnace ashes; the obtained strength parameters were similar to the parameters of the products made of natural materials,

- in the road construction industry - the tests for using waste as a mineral powder for bitumen masses, as an admixture to frost-resistant layers, for the construction of embankments, for building into road subgrades - the tests showed a good waste usefulness as an asphalt filler and the possibility to use relatively little waste admixtures in other applications [12],

- in mining technologies - for the stabilization of voids.

The most interesting identified trends in the recovery of waste - because of the amount possible to use, were the possibilities to use flotation waste as a material for the backfilling of goafs and in highway engineering.

In one piece of research [13] the criteria determining the possibilities of locating waste in goafs and their capacities useful for the location of flotation waste were defined.

As a result of analyses and calculations it was estimated that:

- for old goafs (i.e. the voids formed due the mining carried out in the last 20 years) the capacity of the goafs most useful for the locating waste there was estimated for 9.3 million $\mathrm{m}^{3}$,

- for the post-mining voids generated as a result of the mining forecast till 2055, this capacity will reach from 5.22 million $\mathrm{m}^{3} /$ year up to 7.83 million $\mathrm{m}^{3} /$ year (after 2025).

It was assumed that the maximum coefficient of the use of post-mining voids is $65 \%$. This creates a perspective of developing (in optimum arrangement) of about $30 \%$ of the yearly amount of the generated waste. However, it should be kept in mind that the project, in profit terms, is uneconomical.

Another trend giving a chance to use considerable amounts of the post-flotation waste is highway engineering. In Table 4 the amounts of the waste generated during flotation that 
can be used at various stages of road construction are presented.

Table 4. Using the waste from the flotation process in highway engineering.

\begin{tabular}{|l|l|}
\hline Type of roadworks & \multicolumn{1}{|c|}{$\begin{array}{c}\text { Needed } \\
\text { amount of } \\
\text { waste }\end{array}$} \\
\hline Road embankments $12 \mathrm{~m}$ high, $1 \mathrm{~m}$ long, road of $3^{\text {rd }}$ class & $18 \mathrm{Mg}$ \\
\hline Road embankments $1 \mathrm{~m}$ high, $1 \mathrm{~m}$ long, motorways & $30 \mathrm{Mg}$ \\
\hline Improved subgrade layer, stabilization with emulsion, thickness $=0.2 \mathrm{~m}$ & $0.38 \mathrm{Mg} / \mathrm{m}^{2}$ \\
\hline Base courses mechanically stabilized $-0,2 \mathrm{~m}$ & $0.030 \mathrm{Mg} / \mathrm{m}^{2}$ \\
\hline Mineral-asphalt mastics for the base courses for medium traffic, thickness $=0.10 \mathrm{~m}$ & $0.100 \mathrm{Mg} / \mathrm{m}^{2}$ \\
\hline Asphalt concrete- thickness $=0.10 \mathrm{~m}$ & $0.070 \mathrm{Mg} / \mathrm{m}^{2}$ \\
\hline $\begin{array}{l}\text { Demand for waste for } 1 \mathrm{~km} \text { of the road of the } 3^{\text {rd }} \text { class for the embankment } 1 \mathrm{~m} \\
\text { high, and for the pavement structure for very heavy traffic }\end{array}$ & $21,400 \mathrm{Mg}$ \\
\hline Demand for waste for $1 \mathrm{~km}$ of motorway with an embankment $1 \mathrm{~m}$ high & $40,200 \mathrm{Mg}$ \\
\hline
\end{tabular}

While analysing the program of road construction in the Province of Lower Silesia [14] it was estimated that, theoretically, with the maximum use of the post-flotation waste in this process (and with eliminating the producers of competitive materials) the possible use of waste is on the level of $0,5-1 \mathrm{mln} \mathrm{Mg} /$ year. It should be also noted that as far as highway engineering is concerned, the use of waste as the substitutes of mineral raw materials is hindered by water content in it. Before use that waste should be dried and this increases costs and makes the entire recovery process unprofitable.

Therefore, neither at present nor at any other time there is no alternative for the waste development in the waste neutralization facility.

It is also significant in this situation that at present it is the cheapest way of handling waste, since, although some outlays are needed to maintain the facility, the waste owner, in accordance with the applicable law, does not pay any fee for the storage of mining waste.

\section{Conclusions}

The review of the present state of the development of mining waste and the results of the exemplary pieces of research connected with the possible using them show that:

- the implemented methods of waste rock development can be an illustration and pattern for the functioning of the closed circulatory economy (in other words, for this case, a wasteless economy),

- whereas for the flotation waste, even with the hypothetical assumption of overcoming the technical difficulties connected with some recovery methods, and with neglecting economic results, not always constituting a premise for the use of waste - the amount of the generated processable waste does not give any possibility to use it to the extent that can fulfil the assumption of the circular economy.

Therefore, in reality the processable waste are not used in new projects, it is not any alternative for natural mineral materials:

- not because of lack of initiative of it producers in this field - KGHM Polska Miedź S.A. invests considerable means and actively searches for alternative possibilities to use the post-flotation waste,

- not because of the waste composition and properties - this is a material the properties of that make it possible to use it in most areas where mineral materials are used,

- also not because of lack of innovative solutions in the field of the use of that material; among the worked out recovery methods there are also very inventive ones - practically every year a new method of the use of the post-flotation waste is worked out, confirmed by patent protection $[8,15]$. 
Therefore the fact that not always it is possible to follow the new trends in economy should be accepted. Even when the trends are most correct and right, and as shown by practice $[16,17,18,19]$, the solutions implemented many years ago often turn out to be the best.

\section{References}

1. W. Stahel, "Service, Performance or Goods". Circular Economy Network, (Ellen MacArthur Foundation, 2012)

2. W. McDonough, M. Braungart, Cradle to Cradle: Remaking the Way We Make Things, (New York: North Point Press, 2002)

3. K. Hansen, M. Braungart, D. Mulhall, "Resource Repletion”, in Meyers, Robert A. (ed.), The Springer Encyclopedia of Sustainability Science and Technology, Springer Reference, Berlin, (Heidelberg, 2012)

4. J. Badura, S. A. Miedź, Składowisko Żelazny Most, 603 (2007)

5. I. Kotarska, Gospodarowanie odpadami przemysłowymi, 1005 (2007)

6. I. Kotarska, 13th International Multidyscyplinary Scientific Geoconference SGEM, 2, 735 (2013)

7. K. Stefaniak, M. Wróżyńska, M. Krol, JEE, 18(1), 113 (2017)

8. Patent PL 215185 Sposób wytwarzania polimerycznego materiału budowlanego na bazie siarki odpadowej $i$ odpadów flotacyjnych z flotacji rudy miedzi (United States Patent 215185, USA)

9. K. Rajczyk, KGHM Polska Miedź, SA (2017)

10. A. Łuszczkiewicz, Koncepcje wykorzystania odpadów flotacyjnych z przeróbki rud miedzi w regionie legnicko-głogowskim (Poland, 2000)

11. J. Kudełko, D. Nitek, Cuprum Ore Mining Scientific and Technical Magazine, 3, 51 (2011)

12. D. Sobczyk, D. Socha, J. Więckowska, Prace naukowe Instytutu Górnictwa Politechniki Wrocławskiej, 107, 39 (2004)

13. R. Dębkowski, J. Szczap, J. Kazienko, On possibilities of utilization of flotation wastes in mining technologies in Legnica-Głogów Copper Region mines (Publishing House of the Mineral\&Energy Economy Research Institute, Poland, 2007)

14. Plan of national roads development for 2014 - 2023 (Ministry of Infrastructure, Poland, 2017)

15. Patent PL 222233: Sposób otrzymywania mineralnego materiału wiążącego z odpadów flotacyjnych rud miedzi (KGHM METRACO, SA, 2015)

16. Mining Waste Management in the Baltic Sea Region, (MIN-NOVATION, Poland, 2013)

17. S. Dudka, C.A. Domy, Environmental Impacts of Metal Ore Mining and Processing: A Review, 26(3), 590 (1995)

18. B. Dold, Reviews in Environmental Science and Bio/Technology (Warsava, Poland, 2008)

19. P. Stefanek, A.Serwicki, Bezpieczeństwo Pracy i Ochrona Środowiska w Górnictwie, $\mathbf{6 ( 2 3 8 ) ,} 36$ (2014) 